\title{
An Investigation of the E-Services Quality provided by Kuwait Government Portal
}

\author{
Thalaya Alfozan', Abdullah Alshehab ${ }^{2}$, Hesham Gaderrab ${ }^{3}$ \\ ${ }^{1}$ Computer Science Department, College of Science, Kuwait University, Kuwait, thalaya @cs.ku.edu.kw \\ ${ }^{2}$ Computing Department, College of Basic Education, Public Authority of Applied Education and Training, Kuwait, \\ aj.alshehab@paaet.edu.kw \\ 3Psychology Department, Kuwait University, Kuwait, hesham.gadelrab@ku.edu.kw
}

\begin{abstract}
The unlimited development and extensive use of ICT has helped governments around the world to innovate and improve public services through the advantages of egovernment services. First step of this study was an attempt to measure the quality of e-services provided by the usercentric Kuwait Government Online Portal through investigating the quality standards of e-government services and different quality dimensions of e-government services as identified in the literature. Post examining E-service quality models one model was selected and used to validate the quality of e-services provided by the Kuwait Government Online Portal. A survey was presented to 486 valid participants through an online questionnaire. The result of the survey in general showed a diverse quality results which was around the range of "Neutral". This could be due to having a large number of diverse e-services provided by more than 60 government agencies all enclosed in the Kuwait Government Online Portal. The second step of this study was to validate the result from the survey through conducting a semi-structured interviews by the authors with three top management officials at the government entity responsible for implementing e-government program in Kuwait. The interviews have revealed interesting insights, namely the existence of strong presence of silo-mentality in government entities which could be the main cause for not achieving integrated e-services. Future work will include studying specific e-services and defining suitable categorization that helps in determining their quality. The model that was used in this study was based on high-level dimensions that needs to be broken down into subdiminutions that could contribute to increasing the accuracy of the results of e-service quality evaluation. In addition, measuring the effect of silo-mentality of the government over the quality of e-services in Kuwait is desirable.
\end{abstract}

Key words: E-government services, e-services quality, quality dimensions, survey instrument.

\section{INTRODUCTION}

Due to the rapid and global growth in the use of the Internet and information technology applications, most countries of the world have been keen to keep pace with these developments and shift from the provision of traditional services to electronic services.

The great development and extensive use of information and communication technology (ICT) has helped governments around the world to innovate and improve public services through the advantages of e-government, as e-government is more appropriate and beneficial for citizens and government [1].The e-government is a modern system adopted by governments using modern technology to link their institutions with each other, linking various services with private institutions and citizens, and providing information to citizens, which achieves transparency and improves the quality of services [2].E-government simply means the communication between the government and its citizens via the computer or any devices connected to the Internet, which has many advantages, including time commitment, responsiveness and cost containment [3].E-government services are divided into government-to-government (G2G), government to citizen (G2C), government to business (G2B), government to community (G2SC), and citizen to citizen (C2C) [4], [5].Many positive aspects characterize Egovernment. For example, from the perspective of the public sector, the use of e-government helps increase citizens' confidence in e-government services, leading to an increase in their compliance with laws. Also the e-government through the provision of services via the Internet gains the loyalty of citizens and encourages them to participate in government work. Users can also contact government institutions at any time and from anywhere without the need to visit any government office or agency, thus saving and reducing costs for both parties [6], [7].

The quality of e-government services is the basis for judging the success or failure of e-services provided to users. The success of e-government depends on the existence of several components determined in the components. These components include Information technology and the existence of a sophisticated technical structure in the country, and the elements of the organizational and administrative aspects responsible for the provision of eservices, and legislative components that determine the legal and procedural aspects of the provision of services. However, the associated community components relate to 
successful adaptation of modern technological applications[5], [8].E-government is one way to improve service to citizens and make it easier, which leads to increased citizen satisfaction with government performance and confidence building in government in the long-run [9]. This leads to the importance of the website/portal of the egovernment as part of the government framework in providing services to citizens in the context of advanced information technology. Ensuring the quality of service through government electronic websites arises from the fact that the website is one of the most important channels for providing public services and communication between the government and citizens [10].The importance of egovernment services is determined by the fact that it contributes to the delivery of government services through multiple technical channels in order to help improve the service and its quick and easy access to citizens, which saves them time and effort. It ensures transparency, fairness and credibility in service delivery. It also contributes to overcoming the temporal or geographical impediments to providing service to the citizens in the right place or at the right time [11].

\section{Problem Area}

Established in 2006, the Central Agency for Information Technology (CAIT) is a government organization responsible for setting up the Information Technology plans, standards and supervision of the e-government portal for most of the government agencies in Kuwait. CAIT's role is mainly centered on the following areas:

a. Planning and establishment of information technology policies at the national level.

b. Supervision of the planning and implementation of the e-government projects in coordination with ministries and government agencies.

c. Coordinating the plans and the development of information technology programs among government agencies.

d. Development of the methodologies, standards, and patterns for information technology systems and services.

e. Establishment and management of the official electronic portal/gateway of the State of Kuwait.

f. Supervision and delivery of professional training for the cadres working in the field of industry and technology in the State of Kuwait to build up capabilities related to that area. g. Execution of Public awareness of information technology and its uses for all segments of society.

h. Performing technical feasibility studies for information technology projects with the governmental agencies in coordination with other stakeholders.

CAIT developed the Kuwait Government Online project in 2008. This is a Government Portal which provides a webbased, easy-to-use, mobile-enabled, one-stop, single entry point to user-centric Kuwaiti Government information and eservices. This Portal is available $24 / 7$ to the customers. The Portal is the gateway and first point of visit when citizens $(\mathrm{G} 2 \mathrm{C})$, businesses (G2B) and visitors (Kuwaitis and noneKuwaitis) wish to find information and e-services provided by the portal of the Government of Kuwait.

The implementation of the Portal involved designing a customer-centric portal, reviewing online information \& eservices provided by Government agencies, extracting relevant and useful content, reorganizing and presenting them on the Portal in a consistent manner, searchable and easy-to-use via both web and mobile channels.

This research was designed into two main steps. Step one focuses on investigating and measuring the quality of eservices in Kuwait e-government portal through a survey instrument. The second step was to validate the survey results by interviewing three top management officials at the government entity responsible for implementing egovernment program in Kuwait. The following research questions were used:

- RQ1: What are the quality standards/models of egovernment services?

- RQ2: What are the quality dimensions and models of e-government services?

- RQ3: What is the quality of e-services provided by the Kuwait Government portal?

- RQ4: What is the degree of integration among different e-services?

\section{E-GOVERNMENT}

\subsection{E-Government Concept}

The concept of e-government is a new concept that has been associated with the ICT revolution and its impact on the government sector. The concept of e-government refers to the provision of government services to citizens and business communities with modern communications technologies and networks aimed at raising the efficiency of the performance of those government agencies [12].

Government communication is one of the areas of interest of e-government and one of its important objectives is to provide reliable, clear and real information to citizens about its policies, activities and services[13].

E-government works as an effective tool to increase citizens' communication with government as it focuses at the services 
it provides to citizens, to enhance access to all segments of the society in order to save time and facilitate access to government information and services through the use of information and communications technology in all aspects of government operations in an organized manner to improve government efficiency[14].

\subsection{Characteristics of E-Government}

According to [15]the characteristics of e-government are as follows:

- Not to rely on paper documents as much as electronic documents.

- Enabling teleconferencing through devices connected to e-government networks without the movement of individuals.

- Flexibility and speed in responding to a changing event without being constrained by spatial and temporal limits.

- Dependence on electronic tools in the follow-up of mail or information from the electronic archive and through correspondence.

- Moving from follow-up with paper reports to electronic follow-up.

\subsection{E-Government Objectives}

[16]Summarized e-government as follows:

- Achieving transparency in information and presenting it to citizens through government services continuously.

- Streamlining the working procedures in public organizations.

- Developing and governing management practices in government agencies.

- Providing a favorable investment climate.

- Developing methods of providing services to citizens, providing accurate, time-saving and costeffective access to services and ensuring confidentiality and security of information.

- Achieving e-democracy.

\subsection{Benefits of E-Government}

[17]Listed some benefits of e-government applications as listed below:

- Simplification of procedures, where the application of the e-government system leads to the elimination of bureaucracy.

- Ease of transfer of information with transparency and retention and the possibility of retrieval.

- Promoting transparency, which reduces corruption and cronyism.

- Achieving the principle of objectivity and justice, by providing the necessary information on services to all without discrimination.
- Enabling the electronic transfer of models between government departments, which saves time and effort, and limits mobility between departments.

However, the benefits of e-government applications for citizens is as follow:

- The implementation of the e-government system achieves equality among citizens.

- It provides 24-hour information and services to citizens.

- It shortens the time and provides the effort needed to get the service.

- Designing the website programs and conducting them to obtain the service in a simple way is easy, thus reducing the crowding in public organizations.

\subsection{Quality Standards Of E-Government SERVICES}

There are some criteria that determine the quality of eservices provided by e-government, including [18] website design, reliability, response, security and privacy, availability of information, ease of use.

- Website Design

Website design plays an important role in achieving user satisfaction and is an important element in assessing the quality of e-services.

- Reliability

Achieving reliability indicates the ability of institutions to do what they promise, and that the quality of information provided meets certain criteria, such as accuracy, time, and understandability.

- Response

Response is the degree to which services on the website are useful and without delay, responding to all requests from beneficiaries. The concept of response refers to responding to the inquiries of beneficiaries and solving their problems through the website without delay.

- Security and privacy

The security component is the main focus in dealing with the service provider, as security involves reducing the risk as well as protecting the users when they use the service.

The concept of privacy refers to the avoidance of interference with the 
beneficiary's personal data and information.

- Availability of information

Availability is defined as the ability of the website to provide electronic services around the clock and provide services to the beneficiaries in a timely manner with a high level of accuracy and avoid any technical problems that may lead to hindering the work.

- $\quad$ Ease of use

The concept of ease of use refers to the degree of ease of use of the website and ease of access and search for information.

\section{RELATED WORK}

One study [19] aimed at proposing dimensions to measure the quality of e-government services through seven dimensions: website design, reliability, responsiveness, security and privacy, availability of information, ease of use. One of the main objectives of the research was to increase the awareness of e-Services managers about the quality of eServices in order to help improve the performance of eServices.

[20]Focused on adopting the use of e-government services in developing countries, and found that the more the public interacted with the organization through its website quickly and confidently, the more they were aware of the correct ways of dealing with e-services, and the more it will help to adopt the usage process.

[21]Intended to identify the role of government websites in building trust towards the government and the role of social media in strengthening this trust. The study was conducted on a sample of 2200 internet users and non-users of government services. The study found that there are statistical differences between the level of confidence of customers with government services online and through social media and those who do not deal with government services through these means

[22]Focused on adopting the use of government services by applying the electronic payment of taxes in Taiwan. The study found that the more citizens feel the benefits of using the service electronically, the easier it is to use and achieve advantages compared to the traditional methods of obtaining the service and the possibility of verifying and experimenting with it, and the more it is adopted in the use of these services.

[11]Aimed to analyze the factors in the development of egovernment at the local government level in Poland. The approach usedwas analyzing a group of 18 municipalities. It was found that there were important factors in the development of local e-government in Poland, including the level of social and economic development, access to ICT residents, attitudes and skills, size of administrative units, the attitudes of local authorities and leaders, vision and strategy for e-government development, human resources in offices, and the financial situation of the municipality.

[23]Aimed to assess the current situation of e-government in Nigeria and its compatibility with the national strategy for information technology. The study relies on content analysis of official websites of 36 states and territories in Nigeria in order to identify the features of content and building sites. It was found that out of thirty-six states, only twenty-three of the official websites provided textual information and the results showed that there was little availability of downloadable digital documents on these sites.

\section{E-Government SySTEM QUALITy DimenSION}

\subsection{Service Quality Definition}

One definition of service quality is the difference and comparison between a customer's expectation of a service and the customer's perception of the service provided [24], [25], [26]. However, evaluating and assessing the service quality has been repeated in the literature [24], [25], [27] due to difficulty in measuring tangible components. Table 1 contains some definitions for explanation purposes.

Table 1:E-government service quality definition

\begin{tabular}{|l|l|}
\hline Definition & References \\
\hline $\begin{array}{l}\text { E-Government service quality } \\
\text { could be defined as the degree }\end{array}$ & {$[28]$} \\
to which an e-Government \\
portal or website facilitates the \\
competent delivery of efficient \\
e-services to assist citizens, \\
businesses, and the general \\
public to have a successful \\
interaction with government \\
and its state institutions & \\
\hline $\begin{array}{l}\text { E-government service quality is } \\
\text { defined as 'the degree to which }\end{array}$ & {$[29]$} \\
an e-government web site \\
facilitates the competent \\
delivery of efficient e-services \\
to help citizens, businesses and \\
agencies in achieving their \\
governmental transactions
\end{tabular}




\begin{tabular}{|l|l|}
\hline $\begin{array}{l}\text { failure of any proposed E- } \\
\text { Government projects in the } \\
\text { future }\end{array}$ & \\
\hline E-government service quality is & {$[31]$} \\
defined as the level in which an & \\
e-government web site & \\
facilitates its efficiency in & \\
delivering effective e-services & \\
that can help businesses, & \\
citizens, and agencies in & \\
accomplishing their & \\
governmental transactions & \\
\hline
\end{tabular}

One notorious model was found in the literature named SERVQUAL. The model was developed by [24]. The purpose of the model is to assess customer perceptions of service quality in retail businesses. The objective of the model was to comprehend the differences between customers' expectations and the services provided. The model was divided into five dimensions: Tangibles, Reliability, Responsiveness, Assurance and empathy. However, according to [32] (cited in [26])it was argued that the SERVQUAL model could be applied to the Internet, though there is a necessity to modify its dimensions to be more applicable to technology, making it more technologically relevant and not as dependent on personal interactions.

\subsection{E-Service Quality Model}

[26]Conducted an intense study on the service quality model and proposed 10 dimensions to assess the quality of $\mathrm{e}$ government services, which was based on the dimensions proposed by different researchers in the literature. The research proposes 10 dimensions to assess the quality of egovernment services. The dimensions, their related items and their operational definitions are as follows:

6.2.1 System Availability: all links work properly with continuous access to the website, 24/7.

6.2.2 Privacy/Security: protection and privacy of personal data on all government levels, providing advanced security solutions such as Public Key Infrastructure (PKI), biometrics, digital signature, and encryption technique

6.2.3 Efficiency: Download speed and response time

6.2.4 Fulfillment Availability: availability of correct and detailed service information and flexibility in conducting e services.

6.2.5 Reliability: Do citizens trust that government performs what it promises to do?

6.2.6 Information: E-service contains brief, easy, clear and updated information.
6.2.7 Ease Of Use: user friendly, help functions and ease of navigation.

6.2.8 Website Design: organization of website design.

6.2.9 Interactivity Communication: Citizens' interaction communication at all time for assistance and advice.

6.2.10 Responsiveness: prompt response via communication channels

\subsection{UniDimensionality Of The E-Service Quality Questionnaire}

To investigate wither all items of the e-service questionnaire are unidimensional, and measuring the quality of the eservice construct, we ran exploratory factor analysis (EFA) with a principal components estimator. The analysis resulted in only one factor in which all items have reasonable saturations (see Table 5), with an eigen value of 5.99 (the second nearest extracted factor has an eigen value of 0.98). This dominant factor was able to explain $59.86 \%$ of the variance. In addition, the reliability of this e-service quality factor was very high $($ Cronbach alpha $=.92)$. These results indicate that the items are measuring only one highly reliable dimension, which could be called e-government service quality.

Table 2: Exploratory factor analysis results $(\mathrm{N}=$

\begin{tabular}{|c|c|c|c|}
\hline Item & Value & Item & Value \\
\hline $\begin{array}{l}\text { Links in } \\
\text { government } \\
\text { website } \\
\text { work } \\
\text { properly }\end{array}$ & 0.675 & $\begin{array}{l}\text { Government } \\
\text { website is } \\
\text { trustworthy in } \\
\text { achieving } \\
\text { expected } \\
\text { results/objective }\end{array}$ & 0.842 \\
\hline $\begin{array}{c}\text { Government } \\
\text { website is } \\
\text { available } \\
24 / 7\end{array}$ & 0.614 & $\begin{array}{c}\text { Government } \\
\text { website is easy } \\
\text { to navigate and } \\
\text { provides search } \\
\text { and help } \\
\text { functions }\end{array}$ & 0.842 \\
\hline $\begin{array}{l}\text { Government } \\
\text { website } \\
\text { provides } \\
\text { authenticated } \\
\text { access (PKI, } \\
\text { digital } \\
\text { signature, } \\
\text { biometric) }\end{array}$ & 0.699 & $\begin{array}{l}\text { Government } \\
\text { website is well } \\
\text { organized and } \\
\text { has attractive } \\
\text { appearance }\end{array}$ & 0.809 \\
\hline $\begin{array}{l}\text { Government } \\
\text { website } \\
\text { response } \\
\text { time is } \\
\text { satisfactory }\end{array}$ & 0.795 & $\begin{array}{c}\text { Government } \\
\text { services } \\
\text { areinteractive } \\
\text { and provide the } \\
\text { required } \\
\text { assistance }\end{array}$ & 0.843 \\
\hline $\begin{array}{c}\text { Government } \\
\text { website } \\
\text { provides }\end{array}$ & 0.829 & $\begin{array}{l}\text { Government } \\
\text { website } \\
\text { provides multi }\end{array}$ & 0.748 \\
\hline
\end{tabular}


Thalaya Alfozan et al., International Journal of Advanced Trends in Computer Science and Engineering, 10(2), March - April 2021, 907 - 915

\begin{tabular}{cc} 
content & communication \\
updated, & channels (email, \\
relevant and & live chat, chat \\
easy to & BOT) \\
understand & \\
\hline
\end{tabular}

\section{SurVey Results}

The present study relied on the analytical method, with the study data being collected through a questionnaire that was developed based on the theoretical framework (explained in section 6.2) and previous studies in order to collect data on the study variables in order to reach the answer to the study questions.

\subsection{Sample Description}

486 valid responses were collected through the online questionnaire. The sample was mainly Kuwaiti (87.7\%). About two-thirds $(63.8 \%)$ of the sample were male. Age, highest level of education, expertise with ICTs like websites, and usage rate of e-government websites distributions are presented in Table 3.

Table 3: Sample Characteristics $(\mathrm{N}=486)$

\begin{tabular}{|c|c|c|c|c|c|}
\hline Variable & Levels & $\%$ & Variable & Levels & $\%$ \\
\hline \multirow[t]{5}{*}{ Age } & $\begin{array}{l}\text { 18- less } \\
\text { than } 25\end{array}$ & 10.3 & Education & Diploma & 8.8 \\
\hline & $\begin{array}{l}25-\text { less } \\
\text { than } 35\end{array}$ & 13.6 & & $\begin{array}{l}\text { High } \\
\text { School }\end{array}$ & 13.8 \\
\hline & $\begin{array}{l}35-\text { less } \\
\text { than } 50\end{array}$ & 32.5 & & Bachelors & 49.6 \\
\hline & $\begin{array}{l}50-\text { less } \\
\text { than } 65\end{array}$ & 39.7 & & Masters & 13.4 \\
\hline & $\begin{array}{l}65 \text { or } \\
\text { more }\end{array}$ & 3.9 & & Doctorate & 14.4 \\
\hline \multirow[t]{4}{*}{$\begin{array}{l}\text { E-Gov. } \\
\text { Usage }\end{array}$} & Rarely & 40.9 & $\begin{array}{l}\text { ICT } \\
\text { Websites }\end{array}$ & Poor & 3.9 \\
\hline & Monthly & 27.8 & & Fair & 12.8 \\
\hline & Weekly & 17.9 & & Good & 47.5 \\
\hline & Daily & 13.4 & & Excellent & 35.8 \\
\hline
\end{tabular}

As shown in Table 1, most respondents are between the age of 35- less than $50(32.5 \%)$ and 50- less than $65(39.7 \%)$. Almost half of the respondents $(49.6 \%)$ have a bachelor's degree. $40.9 \%$ of the sample rarely use the e-government websites, but most of them are using the e-government websites at least monthly. In addition, most respondents reported that their expertise with ICTs like websites is good $(47.5 \%)$ or excellent $(35.8 \%)$. Table 4 presents respondents' mean (M) and standard deviations (SD) for each questionnaire item.

Table 4: Mean (M), and standard deviation (SD) for e-service quality questionnaire items $(\mathrm{N}=$

\begin{tabular}{|c|c|c|c|c|c|}
\hline Item & $\mathrm{M}$ & SD & Item & $\mathrm{M}$ & SD \\
\hline $\begin{array}{l}\text { Links in } \\
\text { government } \\
\text { website } \\
\text { work } \\
\text { properly }\end{array}$ & 3.16 & 0.94 & $\begin{array}{l}\text { Government } \\
\text { website is } \\
\text { trustworthy in } \\
\text { achieving } \\
\text { expected } \\
\text { results/objecti } \\
\text { ve }\end{array}$ & 3.13 & 1.03 \\
\hline Governmen & 3.20 & 1.02 & Government & 3.06 & 1.05 \\
\hline
\end{tabular}

\begin{tabular}{|c|c|c|c|c|c|}
\hline $\begin{array}{l}\mathrm{t} \text { website is } \\
\text { available } \\
24 / 7\end{array}$ & & & $\begin{array}{l}\text { website is } \\
\text { easy to } \\
\text { navigate and } \\
\text { provides } \\
\text { search and } \\
\text { help functions }\end{array}$ & & \\
\hline $\begin{array}{l}\text { Governmen } \\
\mathrm{t} \text { website } \\
\text { provides } \\
\text { authenticate } \\
\text { d access } \\
\text { (PKI, } \\
\text { digital } \\
\text { signature, } \\
\text { biometric) }\end{array}$ & 3.34 & 1.01 & $\begin{array}{l}\text { Government } \\
\text { website is well } \\
\text { organized and } \\
\text { has attractive } \\
\text { appearance }\end{array}$ & 3.02 & 1.04 \\
\hline $\begin{array}{l}\text { Governmen } \\
t \text { website } \\
\text { response } \\
\text { time is } \\
\text { satisfactory }\end{array}$ & 2.73 & 1.06 & $\begin{array}{l}\text { Government } \\
\text { service is } \\
\text { interactive and } \\
\text { provides the } \\
\text { required } \\
\text { assistance }\end{array}$ & 2.97 & 1.00 \\
\hline $\begin{array}{l}\text { Governmen } \\
\mathrm{t} \text { website } \\
\text { provides } \\
\text { content } \\
\text { updated, } \\
\text { relevant } \\
\text { and easy to } \\
\text { understand }\end{array}$ & 3.02 & 1.03 & $\begin{array}{l}\text { Government } \\
\text { website } \\
\text { provides multi } \\
\text { communicatio } \\
\text { n channels } \\
\text { (email, live } \\
\text { chat, chat } \\
\text { BOT) }\end{array}$ & 2.76 & 1.09 \\
\hline
\end{tabular}

As shown in Table 3 on average respondents tend to choose the neutral response (with a value of 3 ) for all e-service quality for the government website. It was interesting to see that all standard deviations are close to and around the value of 1 . It seems that respondents do not see the quality of the egovernment service as too low, but nor did they evaluate it as high.

\subsection{Differences In Assessment Of E-Service Quality Related To Study Variables.}

Table 5 presents results of the t-test and ANOVA test for significance of differences in means of e-service quality in relation to nationality, gender, age, education, expertise with ICTs like websites, and usage rate of e-government websites. Due to the large difference in sub-sample sizes between some levels (for example, Kuwaiti and non-Kuwaiti respondents), we ran Levene's test for equality of variance before running t-tests, and ANOVAs. Thisresults in a nonsignificant value $(p>.05)$, indicating that we can proceed with running the corresponding tests.

Table 5: Results of significance of differences in means of eservice quality in relation to various variables $(\mathrm{N}=486)$

\begin{tabular}{lllllll}
\hline Variable & Levels & $\mathrm{M}$ & $\mathrm{SD}$ & $\begin{array}{l}\mathrm{t} / \\
\text { value }\end{array}$ & $\mathrm{F}$ \\
\hline Nationality & Kuwaiti & 29.83 & 7.927 & 4.22 & $\begin{array}{c}\text { Less } \\
\text { than } \\
\end{array}$ \\
& Non-Kuwaiti & 34.37 & 6.874 & & .001 \\
\hline Gender & Female & 32.06 & 8.098 & 3.54 & $\begin{array}{c}\text { Less } \\
\text { than }\end{array}$ \\
& Male & 29.44 & 7.702 & & .001 \\
\hline Age & 18- less than & 29.90 & 7.302 & 0.581 & .677 \\
& 25 & & & & \\
& $25-$ less than & 29.53 & 7.199 & & \\
& 35 & & & & \\
& & & & &
\end{tabular}




\begin{tabular}{llllll} 
& 35- less than & 30.47 & 8.597 & & \\
& 50 & & & & \\
& 50- less than & 30.88 & 7.715 & & \\
& 65 & & & & \\
\hline 65 or more & 28.95 & 8.879 & & .504 \\
\hline Education & Diploma & 30.60 & 9.409 & 0.834 & \\
& High School & 31.09 & 7.489 & & \\
& Bachelors & 30.66 & 8.160 & & \\
& Masters & 30.09 & 6.635 & & \\
& Doctorate & 28.91 & 7.755 & & \\
\hline E-Gov. Usage & Rarely & 29.96 & 7.680 & 3.71 & .012 \\
& Monthly & 29.94 & 7.236 & & \\
& Weekly & 29.78 & 8.259 & & \\
& Daily & 33.42 & 9.124 & & \\
\hline ICT Websites & Poor & 28.00 & 9.304 & 2.65 & .048 \\
& Fair & 31.29 & 7.018 & & \\
& Good & 31.15 & 8.130 & & \\
& Excellent & 29.31 & 7.723 & & \\
\hline
\end{tabular}

According to Table 5 significant differences were found in the mean of e-service quality related to nationality, gender, expertise with ICTs like websites, and usage rate of egovernment websites; but not for age and education. The non-Kuwaiti respondents evaluate the e-government service websites better than the Kuwaiti respondents do. In addition, female users of government websites evaluate the quality of service better, compared with their male counterparts. Furthermore, respondents who use the websites on a daily basis reported better evaluation of service quality than respondents who use the service less frequently. In addition, respondents who have fair and good expertise with ICTs like websites reported better service quality than respondents who report poor or excellent quality. In the next section, the survey results will be validated through semi-structured interview method with three top management officials at the government entity responsible for implementing egovernment program in Kuwait.

\section{SEMI-STRUCTURED INTERVIEWS}

Beside on the results of the survey, a semi-structured interviews [33] were carried out by the authors with three top management executives from the CAIT in Kuwait. The interviews consisted of two main questions, namely:

1. What are the reasons for the lack of integrated EServices onthe Kuwait Government Portal (e.gov.kw)?

2. Did the government of Kuwait execute any plans as an attempt to develop an integrated government framework?

All three interviews resulted in similarrelated results suggesting the following findings:

- Government agencies in Kuwait were built in isolation of each other before the emergence of the Internet. This isolation continues to exist even today.

- The lack of integrated E-Services is due to lack of cooperation between government agencies to share data because most agencies were concern about the lack of data retention policy and the implications of using their data by the CAIT. Such implications include the right to change the data inside their systems, and the risk of misuse of the data. Both concerns could greatly affect data integrity.

- Lack of governance for E-Service delivery through clear objectives and fixed time table. In order to achieve proper service integration we must have proper governance in place to automate service orchestration between agencies involved in completing a particular process.

- An ambitious project worth more than two million dollars was launched few years back to implement a government service bus based on Microsoft Connected Government Framework. The project consisted of the procurement of powerful hardware and specialized software plus consultation service by Microsoft experts. Despite having all required resources, the project did not achieve its objectives. E-Service integrated bus was created successfully and scored high in performance and security but, government agencies werereluctant to connect their systems to it even though more than 400 meeting were made for this purpose only.

From these findings we can point out and determine the existence of silo-mentality in Kuwaite-government. Therefore, the government needs to issue regulations, policies, and procedures that encourage and enforce more collaboration and be ableto create an operating model that can heavily reduce the current isolation and produce a highlevel form of integration and governance to achieve integrated E-Service delivery.This will dramatically increase the quality of E-Services provided by Kuwait Government Portal.

\section{DisCUSSION AND LiMitation}

This study aimed to evaluate the quality of government services enclosed in the Kuwait Government Online Portal, which was launched in 2008. However, the portal consists of more than 60 government entities and provides hundreds of different user-centric services such as paying electric bills, paying road traffic fines, renewal of residency for none Kuwaitis, real estate registry for Kuwaitis and many more. This made the portal heterogeneous and diverse as a whole. This implies that evaluating a diverse portal containing different government entities, which have different interfaces, could have problematic results. Further, as seen in Table 4, the standard deviation and mean were equivalent, which could suggest that participants did the measurement 
approach in a general manner by evaluating the portal as a whole even though it represents 60different government entities.

Table 5 shows significant differences found in the mean of eservice quality related to nationality (non- Kuwaitis represent more than 2 thirds of the population). This could relate to the fact that non-Kuwaitis (13\% of total respondents) use different services than services used by Kuwaitis $(87 \%$ respondents). Further, E-Government service usage (explained in Table 5) shows equivalent results except for respondents with daily usage who had a mean of 33.42 . However, it is very rare for users to use E-Government services on a daily basis unless they are workers or operators for these services.

The quality of e-services provided by the Kuwait Government Portal varies from one entity to another, which means it would be desirable to conduct an independent evaluation of the services provided by each government entity or to define a categorization for e-services to perceive more accurate evaluation of the services as further work.

Respondents with a poor and excellent ICT website knowledge level had a lower mean of quality compared with respondents with fair and good ICT website knowledge, who reported a higher mean of quality. This could suggest that users with poor ICT level background did not properly measure the quality of e-services in the portal. This could be solved by further simplifying the evaluation criteria relating to the evaluation e-service interfaces and/or e-service transactions. However, users with excellent ICT knowledge might perceive the overall quality of the portal as complex and needs more enhancements and improvements.

The study also used semi-structured interviews method, as a validation tool, with top executives responsible for implementing e-government in Kuwait, to further investigate the result of the quality of e-services. The interviews were able to determine the existence of silo-mentality in Kuwait government agencies which has a negative impact over the qualityof e-services that are provided by Kuwait Government Portal.

There is an urgent need for the government to issue regulations, policies, and procedures that diminish the isolation between government entities and push for more effective collaboration. Accordingly, the government needs to establish an operating model for the implementation of integrated government that can operate as a single entity with proper governance to achieve integrated e-service delivery.

\section{CONCLUSION}

This study has investigated the quality standards of usercentric e-government services and different quality dimensions of e-government services as identified in the literature. The study then examined some e-service quality models and used one model to validate the quality of eservices provided by the Kuwait Government Online Portal. A survey was presented to 486 Internet users through an online questionnaire. The results of the survey in general was around the range of "Neutral". This could be due to having to a large number of diverse e-services provided by more than 60 government agencies all enclosed in the Kuwait Government Online Portal. To validate and investigate the survey results, a semi-structured interviews were conducted by the authors with three top management officials at the government entity responsible for implementing egovernment program in Kuwait have revealed very interesting findings namely the existence of silo-mentality in government which is the a key cause for not achieving integrated e-services even though an ambitious project was implemented for the purpose of implementing an integrated government framework. The project was a failure due to strong presence of silo-mentality in different government entities. Future work will include studying specific e-services and defining suitable categorization that helps in determining their quality. The model that was used in this study was based on high-level dimensions that need to be broken down into sub-dimensions that can contribute to increasing the accuracy of the results of e-service quality evaluation. In addition, measuring the effect of silo-mentality of the government over the quality of e-services in Kuwait needs to be investigated.

\section{REFERENCES}

1. Ma L, Zheng Y. National e-government performance and citizen satisfaction: a multilevel analysis across European countries. International Review of Administrative Sciences. 2019 Sep;85(3):506-26.

2. Obi MC. Development and validation of a scale for measuring e-government user satisfaction. Nova Southeastern University; 2009.

3. Sharma M. The Internet, political participation, and e-government in comparative perspective. The University of Texas at Dallas; 2010.

4. Dash S, Pani SK. E-Governance paradigm using cloud infrastructure: benefits and challenges. Procedia Computer Science. 2016 Jan 1; 85:843-55.

5. Al-Shuaili S, Ali M, Jaharadak AA, Al-Shekly M. An Investigate on the Critical Factors that can Affect the Implementation of E-government in Oman. In2019 IEEE 15th International Colloquium on Signal Processing \& Its Applications (CSPA) 2019 Mar 8 (pp. 75-79). IEEE.

6. Rosenberg D. Use of e-government services in a deeply divided society: A test and an extension of the social inequality hypotheses. New Media \& Society. 2019 Feb;21(2):464-82.

7. Arfeen MI, Iqbal J, Mushtaq MJ. Model for eGovernment implementation in Pakistan. In Proceedings of the 10th International Conference on Theory and Practice of Electronic Governance 2017 Mar 7 (pp. 57-61).

8. Sundberg L. Risk and decision in collaborative eGovernment: an objectives-oriented approach. Electronic Journal of e-Government. 2016;14(1):35-46. 
9. Park H, Blenkinsopp J. The roles of transparency and trust in the relationship between corruption and citizen satisfaction. International Review of Administrative Sciences. 2011 Jun;77(2):254-74.

10. Rababah O, Hamtini T, Harfoushi O, Al-Shboul B, Obiedat $\mathrm{R}$, Nawafleh $\mathrm{S}$. Towards developing successful e-government websites. Journal of Software Engineering and Applications. 2013 Nov 1;6(11):559.

11. Perdał R. Factors of local e-government development in Poland: the case of the Poznan Agglomeration. Quaestiones Geographical. 2016 Jun 1;35(2):115-29.

12. Yimbo WO. Analyzing e-government in developing countries using a stages model approach: a case study.

13. Anthopoulos L, Reddick CG, Giannakidou I, Mavridis N. Why e-government projects fail? An analysis of the Healthcare. gov website. Government Information Quarterly. 2016 Jan 1;33(1):161-73.

14. Abu-Shanab EA. E-government familiarity influence on Jordanians' perceptions. Telematics and Informatics. 2017 Feb 1;34(1):103-13.

15. Li Y. On E-government Construction based on Customer Relationship Management. International Journal of Simulation--Systems, Science \& Technology. 2016 Jun 30;17(16).

16. Idris SH. Significant Factors Determining Egovernment Adoption in Selangor, Malaysia. Acta Universitatis Danubius. Economica. 2016;12(3):16372.

17. Almarabeh T, AbuAli A. A general framework for egovernment: definition maturity challenges, opportunities, and success. European Journal of Scientific Research. 2010 Jan;39(1):29-42.

18. Carlson J, O'Cass A. Exploring the relationships between e $\square$ service quality, satisfaction, attitudes and behaviours in content $\square$ driven e $\square$ service web sites. Journal of services marketing. 2010 Apr 27.

19. Alanezi MA, Kamil A, Basri S. A proposed instrument dimensions for measuring e-government service quality. International Journal of $u$-and e-Service, Science and Technology. 2010 Dec;3(4):1-8.

20. Sharma G, Bao X, Qian W. Empirical investigation on adoption of e-governance services in developing countries and ethical issues. International Journal of Advanced Research in Computer Science and Software Engineering. 2012 Dec;2(12):19-27.

21. Hong $H$. Government websites and social media's influence on government-public relationships. Public Relations Review. 2013 Nov 1;39(4):346-56.
22. Liang SW, Lu HP. Adoption of e $\square$ government services: an empirical study of the online tax filing system in Taiwan. Online Information Review. 2013 Jun 14.

23. Oni AA, Okunoye A, Mbarika V. Evaluation of egovernment implementation: The case of state government websites in Nigeria. The Electronic Journal of e-government. 2016;14(1):48-59.

24. Parasuraman A, Zeithaml VA, Berry LL. Servqual: A multiple-item scale for measuring consumer perc. Journal of retailing. 1988 Apr 1;64(1):12.

25. Chingang Nde D, Lukong P. Using the SERVQUAL Model to assess Service Quality and Customer Satisfaction.: An Empirical Study of Grocery Stores in Umeå.

26. Al-Nidawi WJ, kamil Jaafar al-wassiti S, Maan MA, Othman M. A review in E-government service quality measurement. Indonesian Journal of Electrical Engineering and Computer Science. 2018 Jun;10(3):1257-65.

27. Cronin Jr JJ, Taylor SA. Measuring service quality: a reexamination and extension.Journal of marketing. 1992 Jul;56(3):55-68.

28. Mensah IK, Jianing M, Durrani DK. Factors Influencing Citizens' Intention to Use E-Government Services: A Case Study of South Korean Students in China. International Journal of Electronic Government Research (IJEGR). 2017 Jan 1;13(1):14-32.

29. Tan CW, Benbasat I, Cenfetelli R. Understanding the antecedents and consequences of e-Government service quality: transactional frequency as a moderator of citizens' quality perceptions.

30. Bhattacharya D, Gulla U, Gupta MP. E$\square$ service quality model for Indian government portals: citizens' perspective. Journal of Enterprise Information Management. 2012 Apr 13.

31. Alanezi MA, Kamil A, Basri S. A proposed instrument dimensions for measuring e-government service quality. International Journal of $u$-and e-Service, Science and Technology. 2010 Dec;3(4):1-8.

32. Long M, McMellon C. Exploring the determinants of retail service quality on the Internet. Journal of services marketing. 2004.

33. Newcomer, K. E., Hatry, H. P., \& Wholey, J. S. (2015). Conducting semi-structured interviews. Handbook of practical program evaluation, 492. 